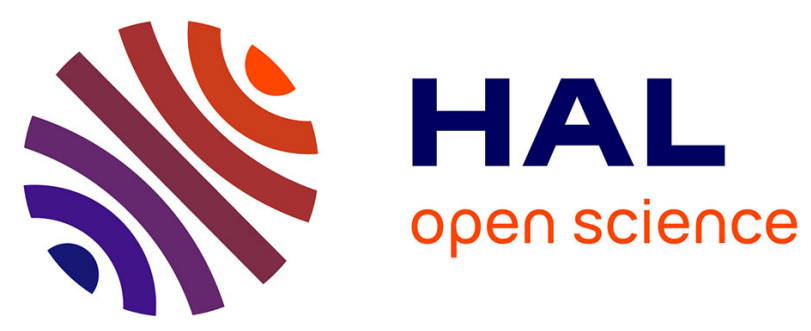

\title{
Adsorption of zinc by biogenic elemental selenium nanoparticles
}

Rohan Jain, Norbert Jordan, Dieter Schild, Eric D. van Hullebusch, Stephan Weiss, Carola Franzen, François Farges, René Hübner, Piet N.L. Lens

\section{To cite this version:}

Rohan Jain, Norbert Jordan, Dieter Schild, Eric D. van Hullebusch, Stephan Weiss, et al.. Adsorption of zinc by biogenic elemental selenium nanoparticles. Journal Chemical Engineering, 2015, 260, pp.855863. 10.1016/j.cej.2014.09.057 . hal-01066678

\section{HAL Id: hal-01066678 https://hal.science/hal-01066678}

Submitted on 22 Sep 2014

HAL is a multi-disciplinary open access archive for the deposit and dissemination of scientific research documents, whether they are published or not. The documents may come from teaching and research institutions in France or abroad, or from public or private research centers.
L'archive ouverte pluridisciplinaire HAL, est destinée au dépôt et à la diffusion de documents scientifiques de niveau recherche, publiés ou non, émanant des établissements d'enseignement et de recherche français ou étrangers, des laboratoires publics ou privés. 


\section{Accepted Manuscript}

Adsorption of zinc by biogenic elemental selenium nanoparticles

Rohan Jain, Norbert Jordan, Dieter Schild, Eric D. van Hullebusch, Stephan

Weiss, Carola Franzen, François Farges, René Hübner, Piet N.L. Lens

PII:

S1385-8947(14)01243-1

DOI:

http://dx.doi.org/10.1016/j.cej.2014.09.057

Reference:

CEJ 12675

To appear in: $\quad$ Chemical Engineering Journal

Received Date: $\quad 1$ August 2014

Revised Date: $\quad 13$ September 2014

Accepted Date: $\quad 15$ September 2014

Please cite this article as: R. Jain, N. Jordan, D. Schild, E.D. van Hullebusch, S. Weiss, C. Franzen, F. Farges, R. Hübner, P.N.L. Lens, Adsorption of zinc by biogenic elemental selenium nanoparticles, Chemical Engineering Journal (2014), doi: http://dx.doi.org/10.1016/j.cej.2014.09.057

This is a PDF file of an unedited manuscript that has been accepted for publication. As a service to our customers we are providing this early version of the manuscript. The manuscript will undergo copyediting, typesetting, and review of the resulting proof before it is published in its final form. Please note that during the production process errors may be discovered which could affect the content, and all legal disclaimers that apply to the journal pertain. 


\title{
Adsorption of zinc by biogenic elemental
}

\section{selenium nanoparticles}

\author{
Rohan Jain ${ }^{a, d^{*}}$, Norbert Jordan ${ }^{b}$, Dieter Schild ${ }^{c}$, Eric D. van Hullebusch ${ }^{d}$, \\ Stephan Weiss ${ }^{b}$, Carola Franzen ${ }^{b}$, François Farges ${ }^{e}$, René Hübner, Piet N.L. Lens ${ }^{a}$ \\ ${ }^{a}$ UNESCO-IHE, Institute for Water Education, Westvest 7, 2611AX Delft, The \\ Netherlands \\ ${ }^{b}$ Institute of Resource Ecology, Helmholtz-Zentrum Dresden-Rossendorf e.V., \\ Bautzner Landstr. 400, D-01328 Dresden, Germany \\ ${ }^{c}$ Institute for Nuclear Waste Disposal, Karlsruhe Institute of Technology, \\ Hermann-von-Helmholtz-Platz 1, 76344 Eggenstein-Leopoldshafen, Germany \\ 'Université Paris-Est, Laboratoire Géomatériaux et Environnement (EA 4508), \\ UPEMLV, 5, Boulevard Descartes - Champs sur Marne, 77454 Marne-la-Vallée, \\ France
}

eInstitut de Mineralogie, de Physique des Materiaux et de Cosmochimie (IMPMC), Muséum national d'Histoire naturelle, Université Pierre-et-Marie Curie and CNRS UMR 7590, Paris, France. 
Manuscript submitted to Chemical Engineering Journal

${ }^{f}$ Institute of Ion Beam Physics and Materials Research

Helmholtz-Zentrum Dresden-Rossendorf e.V., Bautzner Landstr. 400, D-01328

Dresden, Germany

${ }^{*}$ Corresponding author:

Phone: +31 152151715, fax: +31 152122921, e-mail: rohanjain.iitd@gmail.com, mailto:

UNESCO-IHE, Institute for Water Education, Westvest 7, 2611AX Delft, The

Netherlands 


\section{ACCEPTED MANUSCRIPT}

Manuscript submitted to Chemical Engineering Journal

\section{ABSTRACT}

The adsorption of $\mathrm{Zn}^{2+}$ ions onto biogenic elemental selenium nanoparticles (BioSeNPs) was investigated. BioSeNPs were produced by reduction of selenite $\left(\mathrm{SeO}_{3}{ }^{2-}\right)$ in the presence of anaerobic granules from a full scale upflow anaerobic sludge blanket (UASB) reactor treating paper mill wastewater. The BioSeNPs have an iso-electric point at $\mathrm{pH} 3.8$ at $5 \mathrm{mM}$ background electrolyte concentration. X-ray photoelectron spectroscopy showed the presence of a layer of extracellular polymeric substances on the surface of BioSeNPs providing colloidal stability. Batch adsorption experiments showed that the uptake of $\mathrm{Zn}^{2+}$ ions by BioSeNPs was fast and occurred at a $\mathrm{pH}$ as low as 3.9. The maximum adsorption capacity observed was $60 \mathrm{mg}$ of zinc adsorbed per $\mathrm{g}$ of BioSeNPs. The $\mathrm{Zn}^{2+}$ ions adsorption on the BioSeNPs was largely unaffected by the presence of $\mathrm{Na}^{+}$and $\mathrm{Mg}^{2+}$, but was impacted by the presence of $\mathrm{Ca}^{2+}$ and $\mathrm{Fe}^{2+}$ ions. The colloidal stability of BioSeNPs decreased with the increasing $\mathrm{Zn}^{2+}$ ions loading on BioSeNPs (increase in $\mathrm{mg}$ of zinc adsorbed per $\mathrm{g}$ of BioSeNPs), corresponding to the neutralization of the negative surface charge of the BioSeNPs, suggesting gravity settling as a technique for solid-liquid separation after adsorption. This study proposes a novel technology for removal of divalent cationic heavy metals by their adsorption on the BioSeNPs present in the effluent of an UASB reactor treating selenium oxyanions containing wastewaters.

KEYWORDS: adsorption, selenium nanoparticles, zinc removal, XPS analysis, $\zeta-$ potential, colloidal stability 
Manuscript submitted to Chemical Engineering Journal

\section{ABBREVIATIONS}

BioSeNPs - biologically produced (biogenic) elemental selenium nanoparticles

Qe-Me - mg of metal adsorbed per $\mathrm{g}$ of biogenic elemental selenium nanoparticles

UASB - Upflow anaerobic sludge blanket reactor

SEM-EDXS - Scanning electron microscopy - Energy disperse X-ray spectroscopy

XRD - X-ray diffraction

XPS - X-ray photoelectron spectroscopy

EPS - Extracellular polymeric substances 
Manuscript submitted to Chemical Engineering Journal

\section{INTRODUCTION}

Heavy metals at elevated concentrations are toxic to humans, animals and aquatic ecosystems [1]. Removal of heavy metals from wastewater is carried out using a variety of techniques, including chemical precipitation, ion exchange, adsorption, membrane filtration or electrochemical separation [2]. Among these technologies, the adsorption process is advantageous as it is cheap, flexible to operate and maintain, and also generates a high quality effluent, even when metal ions are present in low concentrations in the feed wastewater. Therefore, there is a constant search for adsorbents with higher adsorption capacity, faster kinetics and low cost $[3,4,5]$.

Biologically produced elemental selenium nanoparticles (BioSeNPs) can be a potential new adsorbent for heavy metal cations such as zinc, copper, nickel, lead and cadmium due to the BioSeNPs' amorphous nature [6], small diameter ( 300 nm [6,7]) and negative surface charge ( $\zeta$-potential $-35 \mathrm{mV}$ at neutral $\mathrm{pH}$ and $5 \mathrm{mM}$ background electrolyte concentration) $[8,9]$. Indeed, chemically produced selenium nanoparticles (CheSeNP) adsorb high quantities of copper ( $800 \mathrm{mg}$ of $\mathrm{Cu}$ adsorbed per $\mathrm{g}$ of elemental selenium nanoparticles) [10]. Both CheSeNPs and BioSeNPs adsorb mercury from mercury vapor by forming mercury selenide precipitates $[11,12,13]$. However, chemical elemental selenium nanoparticles production methods entail high production costs and are not environmental benign due to the use of toxic solvents, high temperature and high pressure $[14,15,16]$. In contrast, BioSeNPs can be produced at an ambient temperature without the use of specialized equipments $[7,17]$. Moreover, BioSeNPs are present in the effluent of an upflow anaerobic sludge blanket reactor (UASB) treating selenium containing wastewaters due to microbial reduction of selenium oxyanions 
Manuscript submitted to Chemical Engineering Journal

present in the wastewaters to elemental selenium, thus, further reducing the BioSeNPs' production cost $[6,18]$.

Zinc was selected as a model divalent heavy metal ion as it is used extensively in metallurgy, transport, power and construction industries. Zinc is also a major micronutrient in the human body [19]. However, overexposure to zinc can cause stomach cramps, skin irritations, vomiting, anemia, damage to the pancreas, cause arteriosclerosis, impair immune functioning and disturb protein metabolism [20]. Due to the adverse health impact of overexposure to zinc and the undesirable taste of drinking water at zinc concentration higher than $5 \mathrm{mg} \mathrm{L}^{-1}$, the environmental regulatory agency of the USA and the Food and Agriculture Organization of the United Nations have set limits of $5 \mathrm{mg} \mathrm{L}^{-1}$ in the drinking water $[21,22]$ and the European Commission have set a limit of 5-10 $\mathrm{mg} \mathrm{L}^{-1}$ zinc in domestic wastewater [23]. This manuscript, for the first time, attempts to study the interaction of BioSeNPs with $\mathrm{Zn}^{2+}$ ions. Based on this fundamental understanding, a zinc removal unit and technique can be developed.

In this study, BioSeNPs were produced by the anaerobic reduction of selenite in presence of anaerobic granules. The reduction of selenite is reported to take place through dissimilatory respiration and the BioSeNPs are mainly formed in the periplasm or extracellularly [24,25]. Prior to batch adsorption experiments, BioSeNPs were characterized by X-ray diffraction (XRD), Scanning Electron Microscopy - Energy Dispersive X-ray Spectroscopy analysis (SEM-EDXS), ろ-potential measurements and X-ray photoelectron spectroscopy (XPS). The Qe-Zn (mg of zinc adsorbed per $\mathrm{g}$ of BioSeNPs) was determined as a function of adsorption duration, ionic strength, initial metal solution $\mathrm{pH}$ and concentrations, and in the presence of competing cations $\left(\mathrm{Na}^{+}\right.$, 


\section{ACCEPTED MANUSCRIPT}

Manuscript submitted to Chemical Engineering Journal

$\mathrm{Ca}^{2+}, \mathrm{Mg}^{2+}$ and $\left.\mathrm{Fe}^{2+}\right)$ by means of batch experiments. The effect of $\mathrm{Zn}^{2+}$ ions adsorption on the BioSeNPs' colloidal stability and residual BioSeNPs concentration in the filtrate was determined with the increase in Qe-Zn. The adsorption of $\mathrm{Zn}^{2+}$ ions on the BioSeNPs was characterized using electrophoretic measurements and XPS analysis. For future practical application, removal of $\mathrm{Zn}^{2+}$ ions from synthetic wastewater at low $\mathrm{pH}$ by the BioSeNPs present in the simulated effluent of an UASB reactor was investigated.

\section{MATERIALS AND METHODS}

\subsection{BioSeNPs production and purification}

BioSeNPs were produced by incubating anaerobic granular sludge (13 $\mathrm{g} \mathrm{L}^{-1}$ wet weight) in an oxygen-free growth medium at $30{ }^{\circ} \mathrm{C}$ and $\mathrm{pH} 7.3$ for 14 days. The growth medium and incubation conditions were applied as these were successfully used for the reduction of selenate using the same inoculum [26]. The growth medium contained (in $\left.m g \mathrm{~L}^{-1}\right): \mathrm{NH}_{4} \mathrm{Cl}(300.1), \mathrm{CaCl}_{2} \cdot 2 \mathrm{H}_{2} \mathrm{O}$ (14.7), $\mathrm{KH}_{2} \mathrm{PO}_{4}$ (245.0), $\mathrm{Na}_{2} \mathrm{HPO}_{4}$ (283.9) and $\mathrm{KCl}$ (245.9). Acid \& alkaline trace elements and vitamins were not added to growth medium to avoid their interaction with the formed BioSeNPs. $2.24 \mathrm{~g} \mathrm{~L}^{-1}$ of sodium lactate and $0.86 \mathrm{~g} \mathrm{~L}^{-1}$ of sodium selenite were used, respectively, as carbon and selenium source. This medium was flushed with nitrogen to maintain anaerobic conditions. Anaerobic granular sludge from a full scale UASB reactor used for treating paper mill wastewater in Eerbeek (The Netherlands), described in detail by Roest et al [27], was used as inoculum. 
Manuscript submitted to Chemical Engineering Journal

The production of elemental selenium was confirmed by the appearance of red colorization of the medium. The supernatant was collected by simple decanting and concentrated by centrifuging (Hermle Z36 HK) at $37,000 \mathrm{~g}$ and $4{ }^{\circ} \mathrm{C}$. The pellet was resuspended in Milli-Q $\left(18 \mathrm{M} \Omega^{*} \mathrm{~cm}\right)$ water and purified by the protocol from Dobias et al [28] with minor modification. Briefly, the concentrated BioSeNPs were sonicated in ice cold water for 1 hour at 100 watt and $42 \mathrm{kHz}$. NaOH $(6 \mathrm{~N})$ was added to raise the $\mathrm{pH}$ to 12.5 and the concentrated BioSeNPs were again sonicated at $42 \mathrm{kHz}$ in ice cold water for 2 hours to lyse any remaining biomass present in the supernatant. The $\mathrm{pH}$ was lowered back to 7.3 by addition of $1 \mathrm{~N} \mathrm{HCl}$. An equal volume of $n$-hexane was added and the resultant mixture was kept overnight in a separatory funnel. The BioSeNPs were collected from the aqueous phase and washed three times with Milli-Q $\left(18 \mathrm{M} \Omega^{*} \mathrm{~cm}\right)$ water. After washing, the BioSeNPs were re-suspended in Milli-Q water and the $\mathrm{pH}$ was adjusted to 7.3 by the addition of a few drops of $1 \mathrm{~N} \mathrm{NaOH}$ before adding them for adsorption experiments. The BioSeNPs preparation was carried out in duplicate to ensure that the characteristics of the nanomaterial were reproducible.

\subsection{Batch adsorption experiments}

Batch isotherm studies were carried out at different initial zinc concentrations (5.8 $215.0 \mathrm{mg} \mathrm{L}^{-1}, 960$ minutes of shaking, $\mathrm{pH} 6.5$, added as $\mathrm{ZnCl}_{2}$ ). Time-dependency studies were carried out at different contact times (1 - 960 minutes, $\mathrm{pH} 6.5,70 \mathrm{mg} \mathrm{L}^{-1}$ of initial zinc concentration). No background electrolyte was added for isotherm and timedependency studies. $3 \mathrm{~mL}$ of $0.917 \mathrm{~g} \mathrm{~L}^{-1}$ BioSeNPs at $\mathrm{pH} 7.3$ were added as adsorbent. The experiments were carried out at $30^{\circ} \mathrm{C}$, under atmospheric conditions for 16 hours (this duration was found sufficient to reach equilibrium as observed from 
Manuscript submitted to Chemical Engineering Journal

kinetic experiments). Adsorption of $\mathrm{Zn}^{2+}$ ions was also carried out at various initial zinc solution $\mathrm{pH}(2.0-7.2)$ values with an initial zinc concentration of $70 \mathrm{mg} \mathrm{L}^{-1}$. The theoretical $\mathrm{pH}$ values varied from 2.7 to 7.2 , and were determined by calculating the final concentration of $\mathrm{H}^{+}$ions in the samples while discounting any adsorption reactions. For example, when $3 \mathrm{~mL}$ of BioSeNPs at $\mathrm{pH} 7.3\left(\mathrm{H}^{+}\right.$concentration is $\left.10^{-7.3} \mathrm{M}\right)$ was added to $7 \mathrm{~mL}$ of zinc metal ion solution of $\mathrm{pH} 3\left(\mathrm{H}^{+}\right.$concentration will be $\left.10^{-3} \mathrm{M}\right)$, the final $\mathrm{H}^{+}$ion concentration and the theoretical $\mathrm{pH}$ in the sample will be approximately $7 \times 10^{-4} \mathrm{M}$ and 3.2, respectively. The adsorption experiments were also carried out at various ionic strengths $(0.7-70.0 \mathrm{mM} \mathrm{NaCl})$ and in the presence of competing cations $\left(\mathrm{Ca}^{2+}, \mathrm{Mg}^{2+}\right.$ and $\mathrm{Fe}^{2+}$, added as $\mathrm{CaCl}_{2} \cdot 2 \mathrm{H}_{2} \mathrm{O}, \mathrm{MgCl}_{2} 6 \mathrm{H}_{2} \mathrm{O}$ and $\mathrm{FeCl}_{2} \cdot 4 \mathrm{H}_{2} \mathrm{O}$, respectively). The zinc and competing ions were added simultaneously at the beginning of the adsorption experiments. Simulation by Visual MINTEQ software confirmed that more than $98 \%$ of the total initial zinc added was in the $\mathrm{Zn}^{2+}$ speciation in all the batch adsorption experiments.

As the volumes used in the batch experiments were low, the use of gravity settling for solid-liquid separation was difficult. The samples were, therefore, filtered with a $0.45 \mu \mathrm{m}$ syringe filter (cellulose acetate, Sigma Aldrich) to be analyzed for the residual zinc concentration. Control experiments were carried out to discard the possibility of adsorption of $\mathrm{Zn}^{2+}$ ions to the filter material or by precipitation (more details in Supporting Information (SI)). All the experiments were carried out in duplicate. If the difference in two measurements exceeded $10 \%$, experiments were repeated. The average values and errors of duplicate measurements are presented in the figures. 
Manuscript submitted to Chemical Engineering Journal

2.3 Analysis of BioSeNPs loaded with $\mathrm{Zn}^{2+}$ ions

$5 \mathrm{~mL}$ of BioSeNPs $\left(0.22 \mathrm{~g} \mathrm{~L}^{-1}, \mathrm{pH}\right.$ 7.3) was used for adsorbing different initial zinc concentrations (0.9 - 90.9 $\left.\mathrm{mg} \mathrm{L}^{-1}, \mathrm{pH} 5.5\right)$. The final volume of the samples was $5.5 \mathrm{~mL}$ and the final $\mathrm{pH}$ of the samples varied between 5.8 and 6.5 . The $\zeta$-potential of the BioSeNPs loaded with different concentrations of $\mathrm{Zn}^{2+}$ ions was measured (more details in SI). The samples were then filtered with a $0.45 \mu \mathrm{m}$ syringe filter (cellulose acetate, Sigma Aldrich) and analyzed for the selenium concentration in the filtrate by ICP-MS.

For XPS analysis of BioSeNPs loaded with $\mathrm{Zn}^{2+}$ ions, $90.1 \mathrm{mg} \mathrm{L}^{-1}$ of zinc were added to BioSeNPs $\left(0.917 \mathrm{~g} \mathrm{~L}^{-1}\right)$. The final $\mathrm{pH}$ of the BioSeNPs loaded with zinc after adsorption was 6.2. Prior to XPS analysis, the samples were centrifuged at $37,000 \mathrm{~g}$ for 15 minutes followed by re-suspension in Milli-Q water (see SI for details).

\subsection{Adsorption experiments with simulated wastewaters}

Synthetic wastewater containing zinc was generated by adding chloride salts of $\mathrm{Zn}^{2+}$ (30 $\left.\mathrm{mg} \mathrm{L}^{-1}\right), \mathrm{Mg}^{2+}\left(64.6 \mathrm{mg} \mathrm{L}^{-1}\right), \mathrm{Ca}^{2+}\left(24 \mathrm{mg} \mathrm{L}^{-1}\right)$ and $\mathrm{NH}_{4}^{+}\left(60 \mathrm{mg} \mathrm{L}^{-1}\right)$ as described in Zhao et al. [29], but the $\mathrm{pH}$ was adjusted to 2.9 to prove applicability of the proposed technology for more challenging wastewater. The effluent of an UASB reactor containing BioSeNPs was simulated by using effluent of batch incubations without any post treatment [26]. This effluent contained $\mathrm{Cl}^{-}\left(766 \mathrm{mg} \mathrm{L}^{-1}\right), \mathrm{NO}_{3}{ }^{-}\left(29 \mathrm{mg} \mathrm{L}^{-1}\right), \mathrm{PO}_{4}{ }^{3-}$ $\left(50 \mathrm{mg} \mathrm{L}^{-1}\right), \mathrm{SO}_{4}{ }^{2-}\left(159 \mathrm{mg} \mathrm{L}^{-1}\right)$, BioSeNPs $\left(34.2 \mathrm{mg} \mathrm{L}^{-1}\right)$ and $860 \mathrm{mg} \mathrm{L}^{-1}$ of Carbon Oxygen Demand. The synthetic zinc containing wastewater was mixed with simulated effluent containing BioSeNPs at a ratio of $1: 1$ and $1: 1.5$ for 60 minutes followed by 60 minutes of gravity settling. No filtration was used for solid-liquid separation. After the 


\section{ACCEPTED MANUSCRIPT}

Manuscript submitted to Chemical Engineering Journal

setting, residual zinc and selenium concentrations were measured in the supernatant.

The control experiments were carried out by the same effluent but after removal of BioSeNPs by centrifuging at $37,000 \mathrm{~g}$ and collecting the supernatant.

\subsection{Analytics}

Residual zinc, calcium, magnesium and iron concentrations were measured by Atomic Absorption Spectroscopy (see SI for details). The selenium content of the BioSeNPs was determined by ICP-MS after being dissolved in concentrated $\mathrm{HNO}_{3}$ (see $\mathrm{SI}$ for details). The produced BioSeNPs were characterized by SEM-EDX spectra, XRD, $\zeta$-potential measurements and XPS (more details in SI). All chemicals were of analytical grade and purchased from Sigma Aldrich (The Netherlands).

\section{RESULTS}

\subsection{Characterization of the BioSeNPs}

The BioSeNPs' particles were spherical in shape (Figure 1a) and mainly composed of selenium (Figure 1b). In addition, carbon, oxygen as well as small amounts of nitrogen and sulfur were detected by EDX spectra of the SEM (Figure 1b). The presence of carbon, oxygen, nitrogen and sulfur can be attributed to the presence of extracellular polymeric substances (EPS) attached to the BioSeNPs, which was further confirmed by the XPS data: the $\mathrm{C} 1 \mathrm{~s}, \mathrm{~N}$ 1s and $\mathrm{O}$ 1s peaks were found in the XPS analysis of BioSeNPs (see Figure $\mathrm{S} 1$ in $\mathrm{SI}$ ). These EPS bound to the surface of the BioSeNPs particles provide colloidal stability to the BioSeNPs at different pH values [9]. Note that 
Manuscript submitted to Chemical Engineering Journal

the large Si signal in Figure 1b was due to the use of a silicon wafer during the SEMEDXS measurements.

The BioSeNPs diameter varied between 80 and $260 \mathrm{~nm}$ with a median of $160-180 \mathrm{~nm}$ (see Figure S2 in SI). When filtering the BioSeNPs with $1.0 \mu \mathrm{m}$ and $0.45 \mu \mathrm{m}$ filters, the filtrate fraction of BioSeNPs obtained was $13.9 \%$ and $5.2 \%$ of the original concentration, respectively, suggesting retention of the BioSeNPs to the filter. The presence of EPS (Figure $1 \mathrm{~b}, \mathrm{~S} 1$ in $\mathrm{SI}$ ), that can interact with filter material and also increase the hydrodynamic diameter, can be the cause of this retention [30,31]. XRD patterns of BioSeNPs after purification (see Figure S3 in SI) only show hints for diffuse scattering, suggesting an amorphous nature of the BioSeNPs (Figure S3 in $\mathrm{SI}$ ), as observed in previous studies $[17,32]$. 
Manuscript submitted to Chemical Engineering Journal
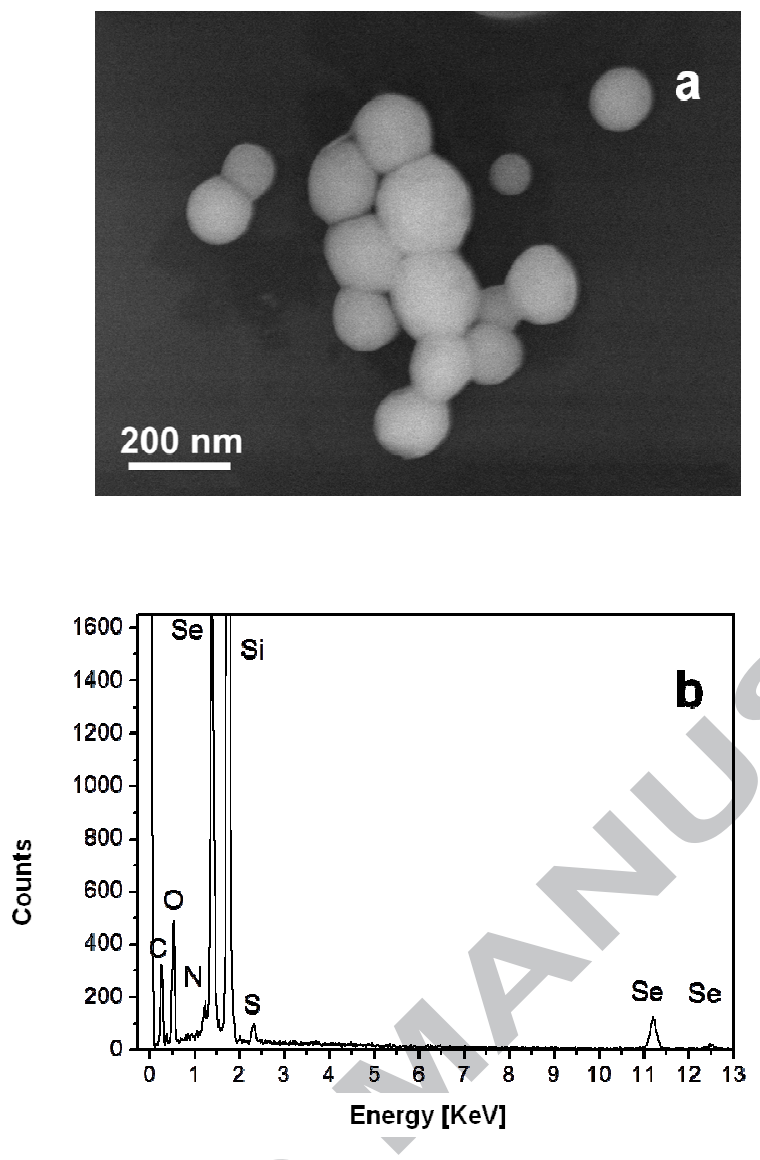

Figure 1. a) Secondary electron SEM image of the BioSeNPs deposited onto a piece of Si wafer and b) EDXS analysis of BioSeNPs.

3.2 Adsorption of $Z n^{2+}$ ions by BioSeNPs

\subsubsection{Time-dependency study}

The equilibrium pH of the samples was 6.5 at all contact times tested. More than $70 \%$ of the $\mathrm{Zn}^{2+}$ ions were adsorbed in the first minute of reaction (Figure 2a). The uptake of $\mathrm{Zn}^{2+}$ ions was completed within 4 hours and remained unchanged for longer contact 
Manuscript submitted to Chemical Engineering Journal

times. All the further experiments were thus carried out for 16 hours to ensure adsorption equilibrium was achieved.
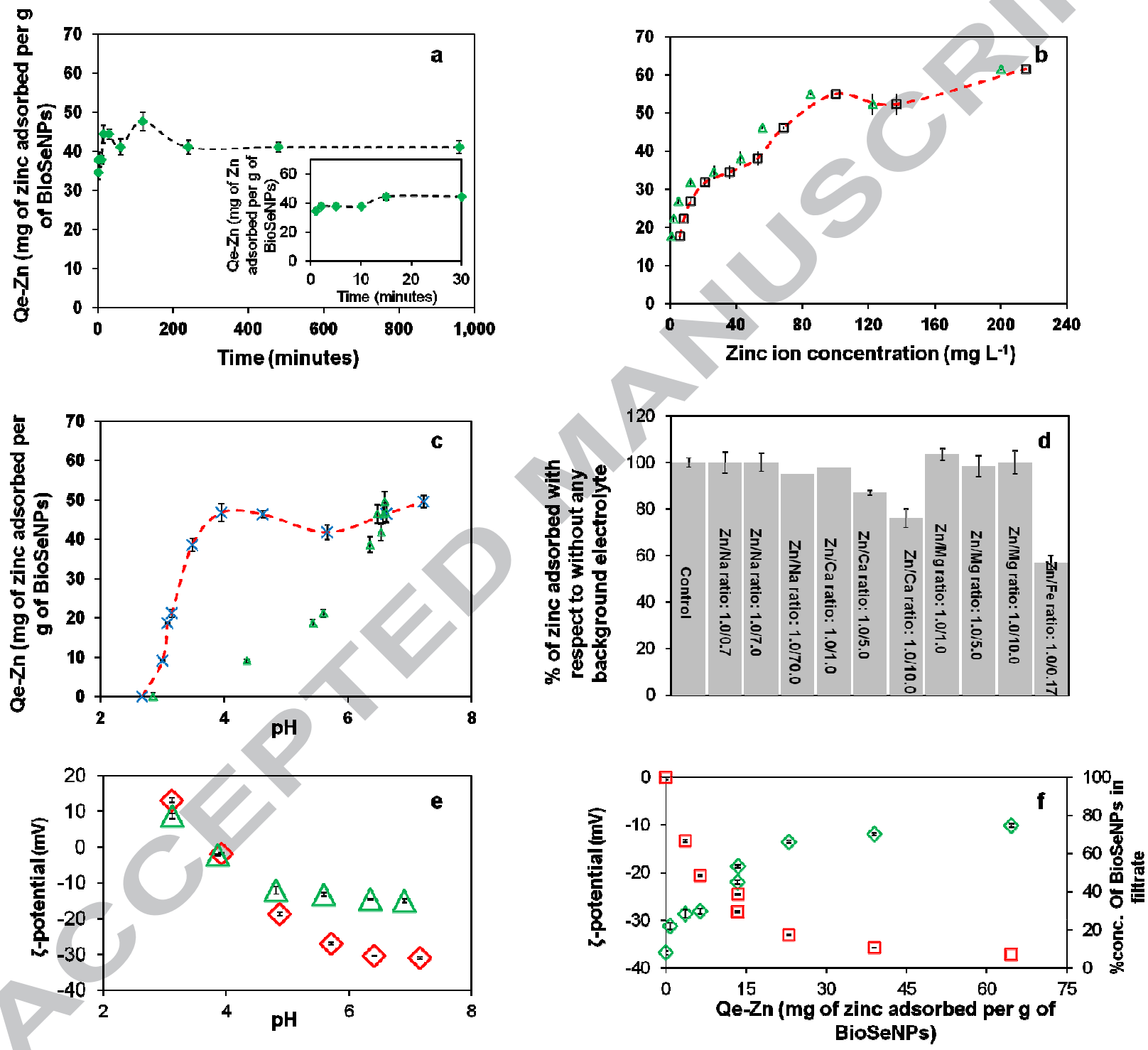

Figure 2. Batch adsorption experiment of $\mathrm{Zn}^{2+}$ ions by BioSeNPs. a) Adsorption at $\mathrm{pH}$ 6.5 , initial zinc concentration of $70 \mathrm{mg} \mathrm{L}^{-1}$ and no background electrolyte with time. 
Manuscript submitted to Chemical Engineering Journal

Zoomed adsorption kinetics for the first 30 minutes presented in the inset. Each data point represents an independent sample; b) Adsorption isotherm at $\mathrm{pH} 6.5$ with different initial ( $\square$ with dotted line) and equilibrium ( $\Delta$ ) zinc concentration; c) Adsorption at $70 \mathrm{mg}$ $\mathrm{L}^{-1}$ zinc with theoretical $\mathrm{pH}(\times$ with dotted line) and equilibrium $\mathrm{pH}(\Delta)$; d) Adsorption at $\mathrm{pH} 6.5$ and $1.0 \mathrm{mM}$ initial zinc concentration with different competing cations, (e) $\zeta$ potential measurements of BioSeNPs $(\diamond)$ and BioSeNPs exposed to $1 \mathrm{mM}$ zinc $(\Delta)$ at a background electrolyte concentration of $5 \mathrm{mM} \mathrm{NaCl}$, (f) $\zeta$-potential measurements of BioSeNPs $(\diamond)$ and \% concentration of BioSeNPs in the filtrate $(\square)$ after exposure to increasing zinc concentrations. The $\%$ of BioSeNPs' concentration in the filtrate was calculated compared to filtration of BioSeNPs without $\mathrm{Zn}^{2+}$ ions adsorption.

\subsubsection{Adsorption isotherms}

The equilibrium $\mathrm{pH}$ remained at 6.5 for all the initial zinc concentrations tested. The adsorption of $\mathrm{Zn}^{2+}$ ions increased with increase in initial zinc concentration (Figure 2b). The adsorption increased sharply when the initial zinc concentration was increased from $5.8 \mathrm{mg} \mathrm{L}^{-1}$ to $21 \mathrm{mg} \mathrm{L}^{-1}$. The plateau was reached at an initial zinc concentration of $36 \mathrm{mg} \mathrm{L}^{-1}$. A further increase in initial zinc concentration from $36 \mathrm{mg} \mathrm{L}^{-1}$ to $215 \mathrm{mg} \mathrm{L}^{-1}$ led to an increase in the adsorption of $\mathrm{Zn}^{2+}$ ions and a second plateau was reached. The maximum adsorption capacity of BioSeNPs achieved was $60 \mathrm{mg}$ of zinc adsorbed per $g$ of BioSeNPs. The adsorption isotherms were modeled with the Langmuir and Freundlich models to obtain the theoretical adsorption capacity (Figure S4 in SI) as explained in Shin et al [33]. The $R^{2}$ values obtained for Langmuir and Freundlich were 


\section{ACCEPTED MANUSCRIPT}

Manuscript submitted to Chemical Engineering Journal

0.980 and 0.977 , respectively. The Qe-Zn predicted by the Langmuir and Freundlich are

62.1 and $45.5 \mathrm{mg}$ of zinc per $\mathrm{g}$ of BioSeNPs. The maximum Qe-Zn predicted by the Langmuir model was close to that observed in the experiments, while the one predicted by the Freundlich model was $25 \%$ lower than that observed in the experiments.

\subsubsection{Effect of variation of $\mathrm{pH}$}

In the $\mathrm{pH}$ study, the amount of $\mathrm{Zn}^{2+}$ ions adsorbed increased with increasing theoretical and equilibrium $\mathrm{pH}$ (Figure 2c). The Qe-Zn was $21.1 \mathrm{mg} \mathrm{g}^{-1}$ (35\% of the maximum adsorption) at a theoretical and equilibrium $\mathrm{pH}$ value of 3.2 and 5.6 , respectively. A steep increase in Qe-Zn to $38.6 \mathrm{mg} \mathrm{g}^{-1}$ (64\% of the maximum adsorption value) was observed when the theoretical and equilibrium $\mathrm{pH}$ value was increased from 3.2 to 3.5 and 5.6 to 6.4 , respectively. The maximum adsorption at $70 \mathrm{mg} \mathrm{L}^{-1}$ initial zinc concentration was $45 \mathrm{mg} \mathrm{g}^{-1}$ (75\% of the maximum adsorption), achieved at theoretical $\mathrm{pH}$ values above 3.9 and almost equal equilibrium $\mathrm{pH}$ value of 6.5 to 6.6 .

\subsubsection{Effect of competing monovalent and divalent cations}

$\mathrm{NaCl}$ was used as background electrolyte in the $\mathrm{Zn} / \mathrm{Na}$ ratios: 1.0/0.7, 1.0/7 and 1.0/70 $\mathrm{mM} / \mathrm{mM}$ to observe their effect on the adsorption of the $\mathrm{Zn}^{2+}$ ions onto BioSeNPs (Figure 2d). The initial and equilibrium $\mathrm{pH}$ values were constant at 6.5. For the 1.0/0.7 and $1.0 / 7 \mathrm{mM} / \mathrm{mM}$ ratio, the adsorption was $100 \%$ as compared to the control experiment (without any electrolyte). With the further decrease in the $\mathrm{Zn} / \mathrm{Na}$ ratio to $1.0 / 70 \mathrm{mM} / \mathrm{mM}$, the adsorption was $95 \%$ of the zinc adsorption in the absence of any background electrolyte. 


\section{ACCEPTED MANUSCRIPT}

Manuscript submitted to Chemical Engineering Journal

$\mathrm{Ca}$ and $\mathrm{Mg}$ were used as competing cations in the $\mathrm{Zn} / \mathrm{X}$ (where $\mathrm{X}=\mathrm{Ca}$ or $\mathrm{Mg}$ ) ratios: $1.0 / 1.0,1.0 / 5.0$ and $1.0 / 10.0 \mathrm{mM} / \mathrm{mM}$ to observe potential competing effects on the adsorption of $\mathrm{Zn}^{2+}$ ions on BioSeNPs (Figure 2d). The initial and equilibrium $\mathrm{pH}$ values were 6.5. The Qe-Zn at $1.0 \mathrm{mM}\left(65.4 \mathrm{mg} \mathrm{L}^{-1}\right)$ initial zinc concentration was $45 \mathrm{mg} \mathrm{g}^{-1}$ in the absence of any competitive ions (Figure 2b). At similar initial experimental conditions, the Qe-Ca (mg of $\mathrm{Ca}$ adsorbed per $\mathrm{g}$ of BioSeNPs) was 18.7 and $51.7 \mathrm{mg} \mathrm{g}^{-1}$, at respectively, 1 and $5 \mathrm{mM}$ of calcium in the absence of zinc. Similarly, the Qe-Mg (mg of Mg adsorbed per $\mathrm{g}$ of BioSeNPs) was 62.6 and $113.8 \mathrm{mg} \mathrm{g}^{-1}$, at respectively, 1 and $5 \mathrm{mM}$ magnesium in the absence of zinc. It is important to note that though the initial experimental conditions were identical for all experiments, the final $\mathrm{pH}$ for $\mathrm{Mg}^{2+}, \mathrm{Ca}^{2+}$ and $\mathrm{Zn}^{2+}$ was 8.3, 8.3 and 6.5, respectively..

With calcium as the competing ion in the ratio $(\mathrm{Zn} / \mathrm{Ca}): 1.0 / 1.0,1.0 / 5.0$ and $1.0 / 10.0$ $\mathrm{mM} / \mathrm{mM}$, the respective Qe-Zn was $98 \%, 87 \%$ and $76 \%\left(42.8,39.2\right.$ and $\left.34.2 \mathrm{mg} \mathrm{g}^{-1}\right)$ of the control experiments $\left(45 \mathrm{mg} \mathrm{g}^{-1}\right)$. The presence of $\mathrm{Ca}^{2+}$, thus, decreases the adsorption of $\mathrm{Zn}^{2+}$ ions at a $\mathrm{Zn} / \mathrm{Ca}$ ratio $<1.0 / 1.0$. With $\mathrm{MgCl}_{2}$ as background electrolyte, the Qe-Zn was almost equal to control experiments $\left(45 \mathrm{mg} \mathrm{g}^{-1}\right): 104 \%, 99 \%$ and $100 \%$ $\left(46.8,44.6\right.$ and $45 \mathrm{mg} \mathrm{g}^{-1}$ ) at the $\mathrm{Zn} / \mathrm{Mg}$ ratio of $1.0 / 1.0,1.0 / 5.0$ and $1.0 / 10.0 \mathrm{mM} / \mathrm{mM}$, respectively. Thus, $\mathrm{Mg}^{2+}$ does not impact zinc ion adsorption under the applied experimental conditions.

To see the competitive effect of $\mathrm{Fe}^{2+}, 0.18 \mathrm{mM}\left(10 \mathrm{mg} \mathrm{L}^{-1}\right)$ of $\mathrm{Fe}^{2+}$ was added externally at an initial metals ion $\mathrm{pH}$ of $4.0\left(\mathrm{Zn}\right.$ concentration was $\left.70 \mathrm{mg} \mathrm{L}^{-1}\right)$. The equilibrium $\mathrm{pH}$ of this experiment was 5.0. The Qe-Zn in these conditions was reduced to $60 \%$ (27 $\mathrm{mg}$ 


\section{ACCEPTED MANUSCRIPT}

Manuscript submitted to Chemical Engineering Journal

$\mathrm{g}^{-1}$ ) of the maximum (45 $\mathrm{mg} \mathrm{g}^{-1}$ ), showing iron has a strong competitive adsorption effect.

\subsubsection{Colloidal stability of BioSeNPs}

The $\zeta$-potential of the BioSeNPs particles produced by anaerobic granules was -31.0 $\mathrm{mV}$ at $\mathrm{pH} 7$ and $5 \mathrm{mM}$ background electrolyte concentration (Figure 2e). Similar negative $\zeta$-potential values of BioSeNPs produced by Bacillus cereus and Bacillus selenatarsenatis were reported in other studies $[8,9]$. The iso-electric point of BioSeNPs particles was at pH 3.8 as compared to 3.5 of selenium nanoparticles produced by $B$. selenatarsenatis [9]. The adsorption of zinc on BioSeNPs has led to less negative $\zeta$ potential values (Figure $2 \mathrm{e}, \mathrm{f}$ ). No appreciable change in the iso-electric point of BioSeNPs loaded with $\mathrm{Zn}^{2+}$ ions was observed. In Figure 2f, with the increase in Qe-Zn from 0 to $23.0, \zeta$-potential values changed from -36.7 to $-13.4 \mathrm{mV}$. When the Qe- $\mathrm{Zn}$ value increases to 64.5 , the $\zeta$-potential became less negative $(-10.2 \mathrm{mV})$. Figure $2 \mathrm{f}$ also shows a decrease in concentration of BioSeNPs in the filtrate after adsorption of zinc with the increase in Qe-Zn. The concentration of BioSeNPs decreased by more than $92 \%\left(240 \mu \mathrm{g} \mathrm{L}^{-1}\right.$ in the filtrate after adsorption and filtration as compared to $3200 \mu \mathrm{g} \mathrm{L}^{-1}$ in the filtrate after filtration only) with a Qe-Zn of $62 \mathrm{mg}$ of zinc adsorbed per $\mathrm{g}$ of BioSeNPs. It is important to note that after adsorption and filtration, $99.9 \%$ of the added BioSeNPs were retained in the filter.

\subsection{XPS analysis}

During the XPS analysis of BioSeNPs, the Se $3 d_{5 / 2}$ binding energy for the BioSeNPs was observed at $55.3 \mathrm{eV}$ (Figure 3a). This is in good agreement with binding energy 


\section{ACCEPTED MANUSCRIPT}

Manuscript submitted to Chemical Engineering Journal

values previously reported in the literature for elemental selenium (see Tables S1 and $\mathrm{S} 2$ in SI). The assignment of the doublet of $\mathrm{Se} 3 \mathrm{~d}_{3 / 2}$ and Se $3 \mathrm{~d}_{5 / 2}$ is often overlooked in the literature and authors only refer to $\mathrm{Se} 3 \mathrm{~d}$, probably due to the use of nonmonochromatic X-ray excitation. In agreement with observations of Guo and Lu [34], the binding energies of the different elemental selenium phases, e.g. amorphous, trigonal or monoclinic are comparable. No additional peaks at binding energies corresponding to other selenium oxidation states were detected (Figure 3a). XPS confirmed, therefore, the formation of BioSeNPs particles via selenium(IV) reduction.

At $53.7 \mathrm{eV}$, a peak corresponding to the $\mathrm{Fe} 3 \mathrm{p}$ elemental line was observed. The presence of $\mathrm{Fe}$ is due to the use of anaerobic granular sludge for BioSeNPs production. The total Fe concentration measured after dissolving BioSeNPs in $\mathrm{HNO}_{3}$ was $5.4 \pm 2.5 \%$ $(n=4) w / w$ of the BioSeNPs. As the signals of Fe in XPS were weak, assignment of the oxidation state of Fe was not possible. Since XPS is a surface probing technique, this suggests that most Fe was not present on the surface of the BioSeNPs but entrapped inside the BioSeNPs. 
Manuscript submitted to Chemical Engineering Journal
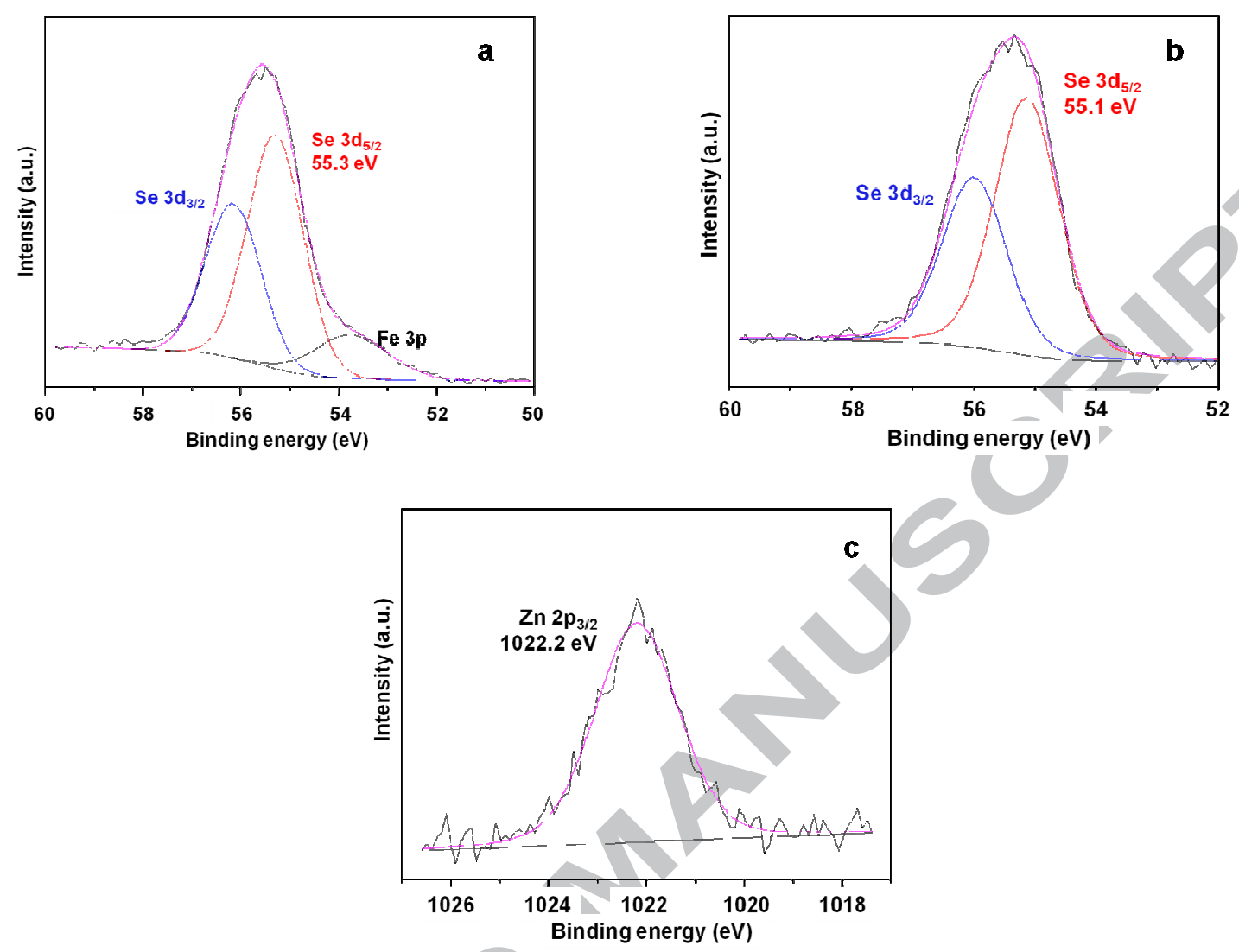

Figure 3. (a) XPS spectra of BioSeNPs confirming the production of elemental selenium Se 3d lines of BioSeNPs and XPS spectra of BioSeNPs loaded with zinc, (b) Se 3d lines and (c) $Z n 2 p_{3 / 2}$ lines.

The signal of $\mathrm{C}$ 1s can be fitted into three components with binding energies located at 284.8, 286.3 and $288.1 \mathrm{eV}$, corresponding to hydrocarbon chains $\left(\mathrm{C}_{\mathrm{x}} \mathrm{H}_{\mathrm{y}}\right)$, alpha-carbon $(\alpha-\mathrm{C})+\mathrm{C}-\mathrm{N}$, and carboxylic acid ( $\mathrm{COOH}$ groups), respectively $[35,36]$. The $\mathrm{N} 1 \mathrm{~s}$ peak is centered at $400.1 \mathrm{eV}$ and lays in the range corresponding to nitrogen containing groups (such as amine or amide groups) $[17,36,37]$. The $O 1$ s signal can be fitted into two components at 531.7 and $532.9 \mathrm{eV}$, corresponding to hydroxyl $(-\mathrm{OH})$ and carboxylate $(-\mathrm{COOH})$ groups, respectively [38] (see Figure S1 in the SI). 
Manuscript submitted to Chemical Engineering Journal

During the XPS analysis of BioSeNPs loaded with zinc, the Se $3 d_{5 / 2}$ binding energy of the $\mathrm{Zn}^{2+}$ ions loaded on the BioSeNPs was centered at $55.1 \mathrm{eV}$ (Figure 3b), while the Se $3 p_{3 / 2}$ line was found at $161.4 \mathrm{eV}$. These binding energy values are in agreement with the energies found for the no zinc exposed BioSeNPs, corresponding also to elemental selenium (see Tables S1 and S2 in SI). No significant differences in the $\mathrm{C} 1 \mathrm{~s}, \mathrm{~N} 1 \mathrm{~s}$ and $\mathrm{O}$ 1s lines were observed after interaction with $\mathrm{Zn}^{2+}$ ions.

The binding energy of the $\mathrm{Zn} 2 \mathrm{p}_{3 / 2}$ signal is located at $1022.2 \mathrm{eV}$ (Figure $3 \mathrm{c}$ ). The difficulty of attributing this binding energy is due to the fact that $\mathrm{Zn}$ compounds such as $\mathrm{ZnO}, \mathrm{ZnSe}, \mathrm{ZnCO}_{3}$ or $\mathrm{Zn}(\mathrm{OH})_{2}$ (NIST Database) [39] show similar $\mathrm{Zn} 2 \mathrm{p}_{3 / 2}$ binding energies (refer to Table S3 in SI).

\subsection{Zinc removal from synthetic wastewater}

Figure 4 demonstrates the zinc removal from simulated zinc containing wastewater. The final $\mathrm{pH}$, after the mixing and settling of the synthetic metal wastewater fed with the simulated UASB effluent containing BioSeNPs and without BioSeNPs, was between 7.6

- 7.8. $97.2 \pm 0.2 \%$ and $97.2 \pm 0.1 \%$ of the total zinc was removed at $1: 1$ and $1: 1.5$ ratios, respectively, fed with BioSeNPs containing UASB effluent. In the control experiments, $80.7 \pm 0.7 \%$, and $79.4 \pm 4 \%$ of total zinc was removed $1: 1$ and $1: 1.5$ ratios, respectively. The enhanced removal of zinc in synthetic wastewaters in comparison to control experiments is due to the presence of BioSeNPs. The removal of zinc in control experiments was due to precipitation of zinc in form of $\mathrm{ZnO}, \mathrm{Zn}(\mathrm{OH})_{2}, \mathrm{Zn}_{3}(\mathrm{PO})_{2}$ and complexes with organic carbon as predicted by Visual MINTEQ. The final zinc concentrations, when BioSeNPs were added, for ratio 1:1 and 1:1.5 were 0.39 and 0.32 
Manuscript submitted to Chemical Engineering Journal

$\mathrm{mg} \mathrm{L}^{-1}$, respectively, which is well below the regulatory discharge limits $[21,22,23]$ and 10 times less than zinc concentration in the control experiments. More than 97 and $80 \%$ of added BioSeNPs could be retained in the settled sludge (comprising BioSeNPs and $\mathrm{Zn}$ ) at the ratio of $1: 1$ and 1:5, respectively.

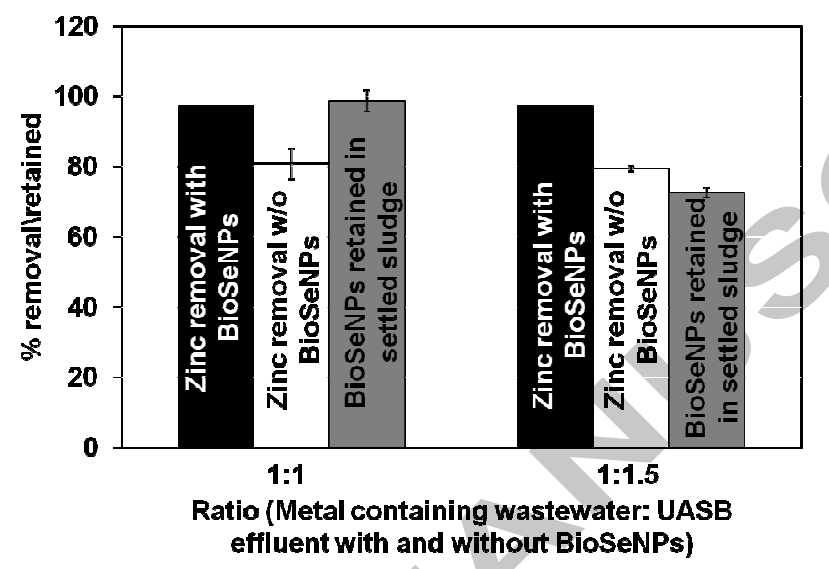

Figure 4. Zinc removal efficiency ( $\mathbf{m})$ and BioSeNPs retention ( $\mathbf{m})$ in the effluent and settled sludge, respectively, at different ratios of synthetic metal wastewater and simulated UASB effluent containing BioSeNPs. Zinc removal efficiency in the control experiments $(\square)$ at different ratio when synthetic metal wastewater is mixed with UASB effluent without BioSeNPs.

\section{DISCUSSION}

\subsection{Mechanisms of $\mathrm{Zn}^{2+}$ adsorption onto BioSeNPs at near-neutral $\mathrm{pH}$}

This study demonstrated, for the first time, that adsorption of $\mathrm{Zn}^{2+}$ ions on BioSeNPs is carried out by different mechanisms depending on the initial zinc concentrations. The $\zeta-$ 
Manuscript submitted to Chemical Engineering Journal

potential of BioSeNPs loaded with $\mathrm{Zn}^{2+}$ ions vs Qe-Zn (Figure 2f) has the same doubleplateau as the adsorption isotherm of $\mathrm{Zn}^{2+}$ ions (Figure $2 \mathrm{~b}$ ), suggesting two kinds of sorption mechanisms prevail at near neutral $\mathrm{pH}$ values. The double-plateau isotherm for $\mathrm{Zn}^{2+}$ adsorption on BioSeNPs observed at initial and equilibrium pH of 6.5 (Figure 2b) might be due to the presence of high and medium affinity sites on the surface of the adsorbent, as suggested in the adsorption of zinc, cadmium, copper and nickel by amorphous hydrous manganese dioxide [40] or zinc adsorption by hydroxy intercalated Al and Zr-pillared bentonite [41]. Alternatively, the double-plateau adsorption isotherm can be explained by the BET type IV isotherm [42]. This type of isotherm proposes the formation of adsorbate monolayers on the site, followed by precipitation of adsorbate in the pores of the adsorbent.

XPS analysis of BioSeNPs loaded with $\mathrm{Zn}^{2+}$ confirms the formation of zinc precipitates on the surface of BioSeNPs (Figure 3c), as predicted in BET type IV isotherm. However, the XPS analysis of BioSeNPs loaded with $\mathrm{Zn}^{2+}$ does not allow to assign unambiguously the zinc compound found on the surface, since $\mathrm{ZnO}, \mathrm{Zn}(\mathrm{OH})_{2}, \mathrm{ZnCO}_{3}$ and $\mathrm{ZnSe}$ exhibit very similar $\mathrm{Zn} 2 \mathrm{p}_{3 / 2}$ binding energies (see Table S3 in SI). The possibility of the presence of $\mathrm{ZnO}, \mathrm{Zn}(\mathrm{OH})_{2}$ and $\mathrm{ZnCO}_{3}$ can be explained on the basis of increased concentrations of $\mathrm{Zn}^{2+}$ ions in the electrical double layer as compared to the bulk solution due to electrostatic attractions between the high negative $\zeta$-potential of BioSeNPs and the positive charge of the $\mathrm{Zn}^{2+}$ ions leading to precipitation of $\mathrm{Zn}(\mathrm{OH})_{2}$, $\mathrm{ZnO}$ or $\mathrm{ZnCO}_{3}$ on the surface of the BioSeNPs.

ZnSe could also be present on the surface of BioSeNPs following the disproportionation of elemental selenium to selenium(IV) and selenium(-II) leading to 
Manuscript submitted to Chemical Engineering Journal

ZnSe formation $[43,44,45]$. Indeed, based on solubility products, the formation of HgSe and $\mathrm{Ag}_{2} \mathrm{Se}$ through disproportionation of elemental selenium into selenide and selenite was reported to be highly favorable, in comparison to ZnSe whose formation was considered to be less favorable [43]. Such a disproportionation reaction of elemental selenium was experimentally observed during synthesis of CuSe and $\mathrm{Ag}_{2} \mathrm{Se}$ in alkaline and hydrothermal conditions [46], however not at the experimental conditions applied in this study $\left(\mathrm{pH}=6.5, \mathrm{~T}=30^{\circ} \mathrm{C}\right)$. Preliminary analysis of Extended X-ray Absorption Fine Structure (EXAFS) data of BioSeNPs loaded with $\mathrm{Zn}^{2+}$ ions at $\mathrm{Zn} \mathrm{K}$-edge suggests that the first neighbor of $\mathrm{Zn}$ is $\mathrm{O}$ (data not shown). The $\mathrm{Zn}$ precipitate can be either $\mathrm{ZnO}$, $\mathrm{Zn}(\mathrm{OH})_{2}, \mathrm{ZnCO}_{3}$ or even $\mathrm{Zn}$-organic complexes, rather than $\mathrm{ZnSe}$. To better evaluate the chemical environment of zinc at the BioSeNPs surface, further analysis of the EXAFS data is required, which is beyond the scope of the present study.

4.2 Mechanisms of $\mathrm{Zn}^{2+}$ ions adsorption onto BioSeNPs at different $\mathrm{pH}$

The adsorption of $\mathrm{Zn}^{2+}$ ions on BioSeNPs follows different mechanisms at different solution $\mathrm{pH}$. At initial $\mathrm{pH}$ values from 2.9 to 3.8 (the theoretical $\mathrm{pH}$ values were calculated to be 3.0 to 4.0 and the equilibrium $\mathrm{pH}$ values varied from 4.4 to 6.6 ), the $\mathrm{Zn}^{2+}$ ions adsorption on BioSeNPs followed a ligand-like (type II) adsorption mechanism [40]. In the ligand-like adsorption, ligands can bind to solid surfaces by replacing $\mathrm{OH}^{-}$ and decreasing repulsion between solids and cations, which in turn assist in binding of the cations to the same site as the ligand or at some other sites. Ligands also increase the number of sites taking part in adsorption by maintaining electro-neutrality on the surface of the adsorbent. The excess of $\mathrm{OH}^{-}$or lack of $\mathrm{H}^{+}$ions was observed in the samples while carrying out the mass balance for $\mathrm{H}^{+}$ions for the adsorption of $\mathrm{Zn}^{2+}$ ions 


\section{Manuscript submitted to Chemical Engineering Journal}

by BioSeNPs at initial $\mathrm{pH}$ values of 2.9 to 3.8 . The $\mathrm{Zn}^{2+}$ ions adsorption was highly correlated to the $\mathrm{H}^{+}$sorbed during this $\mathrm{pH}$ range $\left(\mathrm{R}^{2}=0.99\right.$, see Figure $\left.\mathrm{S} 5 \mathrm{in} \mathrm{SI}\right)$. This high correlation suggests that at low $\mathrm{pH}$, a release of $\mathrm{OH}^{-}$ions or adsorption of $\mathrm{H}^{+}$ions takes place during the interaction of $\mathrm{Zn}^{2+}$ ions with the BioSeNPs. A similar increase in equilibrium $\mathrm{pH}$ was reported during adsorption of $\mathrm{Cu}^{2+}$ at initial $\mathrm{pH}$ of 3.0 by polyglycidyl methacrylate and polyethyleneimine [47]. The equilibrium $\mathrm{pH}$ varied between 4.8 and 5.9 , increasing with increase of the background chloride ion concentrations, suggesting ligand-like (type II) assisted adsorption [40].

To quantify the amount of the chloride ions adsorbed, experiments were carried out at an initial zinc concentration of $60.0 \mathrm{mg} \mathrm{L}^{-1}$, chloride ion concentration of $82.8 \mathrm{mg} \mathrm{L}^{-1}, \mathrm{pH}$ of 3.7 and with $2.2 \mathrm{~g} \mathrm{~L}^{-1}$ of BioSeNPs. The Qe-Cl was $1.8 \mathrm{mg}$ of chloride adsorbed per $\mathrm{g}$ of BioSeNPs (see details for $\mathrm{Cl}^{-}$measurement in $\mathrm{SI}$ ). The adsorption of $\mathrm{Cl}^{-}$points to the possibility of the presence of anion assisted $\mathrm{Zn}^{2+}$ ions adsorption by BioSeNPs [40]. Since the Qe-Cl is much lower than that of Qe-Zn $\left(25.5 \mathrm{mg} \mathrm{g}^{-1}\right)$ at these experimental conditions, anion assisted $\mathrm{Zn}^{2+}$ ions adsorption is most likely not the dominant mechanism or is only valid for a small $\mathrm{pH}$ range.

At the theoretical $\mathrm{pH}$ value of 7.2 , the replacement of the $\mathrm{H}^{+}$ion by $\mathrm{Zn}^{2+}$ ions on the surface of BioSeNPs was suggested by the drop in the equilibrium $\mathrm{pH}$ to 6.5 from theoretical $\mathrm{pH}$ of 7.2. This release of $\mathrm{H}^{+}$ion was also observed when the theoretical $\mathrm{pH}$ value was increased from 4.0 to 5.7 .

4.3 Effect of competing ions on $\mathrm{Zn}^{2+}$ ions adsorption 


\section{ACCEPTED MANUSCRIPT}

Manuscript submitted to Chemical Engineering Journal

The effect of $\mathrm{Zn}^{2+}$ ions adsorption on BioSeNPs in the presence of common competing ions as $\mathrm{Na}, \mathrm{Ca}, \mathrm{Mg}$ and $\mathrm{Fe}$ is important to assess the applicability of BioSeNPs for real wastewaters. To this point, it was observed that the increase in $\mathrm{NaCl}$ concentration from $0.001 \mathrm{M}$ to $0.1 \mathrm{M}$, there was no significant effect on the zinc ion adsorption by BioSeNPs (Figure 2d). This suggests that the $\mathrm{Zn}^{2+}$ ions are adsorbed on the surface of BioSeNPs via inner sphere complexation [48].

The relative increase in adsorption of the cations either follows a decrease in ionic radius or an increase in electronegativity of the metal ion or an increase in ratio of the ionisation potential and ionic radius [49]. Qe-Mg $>\mathrm{Qe}-\mathrm{Zn}>\mathrm{Qe}-\mathrm{Ca}$, which is explained by the trend in ionic radius of the ions: $\mathrm{Mg}^{2+}<\mathrm{Zn}^{2+}<\mathrm{Ca}^{2+}$ (see Table $\mathrm{S} 4$ in Sl). However, the relative preference of cations for adsorption by BioSeNPs follows the trend in the ratio of ionisation potential and ionic radius, which is the highest for $\mathrm{Zn}^{2+}$ (-1.03), lower for $\mathrm{Ca}^{2+}(-2.89)$ and the lowest for $\mathrm{Mg}^{2+}(-3.63)$, thus implying that $\mathrm{Zn}^{2+}$ would outcompete calcium and magnesium at the equimolar ratios.

The ratio of ionization potential and ionic radius for $\mathrm{Fe}^{2+}(-0.77)$ exceeds that of $\mathrm{Zn}^{2+}$ $(-1.03)$, thus $\mathrm{Fe}^{2+}$ would outcompete zinc at equimolar ratio. The effect of entrapped $\mathrm{Fe}$ in BioSeNPs on its adsorption capacity could not be measured as it is impossible to remove Fe entirely from the BioSeNPs without altering or destroying them. The entrapped $\mathrm{Fe}$ is, however, unlikely to have inhibited the adsorption of $\mathrm{Zn}^{2+}$ on BioSeNPs as the majority of Fe was not present on the surface of BioSeNPs (Figure 3a).

\subsection{Colloidal stability of BioSeNPs}


Manuscript submitted to Chemical Engineering Journal

The increase of $\mathrm{Zn}^{2+}$ ions adsorption with increasing $\mathrm{pH}$ can be ascribed to the change in $\zeta$-potential of the BioSeNPs. The $\zeta$-potential of the BioSeNPs is negative at $\mathrm{pH}$ values above the iso-electric point $(\mathrm{pH} 3.8)$ and becomes more negative with increasing $\mathrm{pH}$. The negative charge on the surface of BioSeNPs attracts the $\mathrm{Zn}^{2+}$ ions and thus, the more negative charge, the stronger will be the attraction and hence increases the adsorption [4]. Furthermore, the change in $\mathrm{pH}$ leads to deprotonation of functional groups present on the surface of BioSeNPs (see Figure S1 in SI) which, in turn, provides more binding sites to $\mathrm{Zn}^{2+}$ ions and thus increases adsorption.

The interaction of $\mathrm{Zn}^{2+}$ ions and BioSeNPs leads to less negative BioSeNPs loaded with zinc, suggesting that the zinc is adsorbed either by electrostatic interactions or by covalent bond formation (Figures $2 \mathrm{e}, \mathrm{f}$ and Table $\mathrm{S} 5$ in $\mathrm{SI}$ ). The same trend was observed for interaction of BioSeNPs with $\mathrm{Ca}^{2+}$ and $\mathrm{Mg}^{2+}$ (see Figure $\mathrm{S} 6$ in SI) and was also observed during the interaction of calcium ions with BioSeNPs produced by Bacillus selenatarsenatis [9]. No appreciable shift in iso-electric point of BioSeNPs loaded with zinc was observed (Figure 2e). This can be attributed to the relatively small amount of zinc adsorption at an equilibrium $\mathrm{pH}$ value of 4 . A similar observation was made during adsorption of $\mathrm{U}(\mathrm{VI})$ on $\mathrm{MnO}_{2}$ [48].

The $\zeta$-potential becomes less negative at increasing Qe-Zn (Figure 2f, Table S5 in SI). This suggests that as the load of $\mathrm{Zn}^{2+}$ ions on the surface of BioSeNPs increases, the colloidal stability of BioSeNPs decreases. The effect of lower colloidal stability of BioSeNPs loaded with $\mathrm{Zn}^{2+}$ ions led to settling and a lower concentration of BioSeNPs in the filtrate: $99.9 \%$ of retention of total added BioSeNPs on the filter was achieved (240 $\mu \mathrm{g} \mathrm{L}^{-1}$ of selenium concentration after zinc adsorption and filtration; $3200 \mu \mathrm{g} \mathrm{L}^{-1}$ 


\section{ACCEPTED MANUSCRIPT}

\section{Manuscript submitted to Chemical Engineering Journal}

after only filtration, $220,000 \mu \mathrm{g} \mathrm{L}^{-1}$ of added BioSeNPs, Figure 2f). Thus, the heavy metals loaded on BioSeNPs can be separated from the liquid phase by simple gravity settling.

\subsection{Practical implications}

This study demonstrated that the adsorption of $\mathrm{Zn}^{2+}$ ions can be performed at acidic $\mathrm{pH}$ values ( $\mathrm{pH}$ 3.9). This is an interesting characteristic as the $\mathrm{pH}$ of the metal containing wastewaters such as electroplating industry wastewater or acid mine drainage wastewater [26] varies from highly acidic to near neutral $[29,50,51,52]$, where activated carbon is unable to adsorb zinc [53]. Though the adsorption capacity of BioSeNPs is low in comparison to Dowex HCR S/S resin (Qe $172.2 \mathrm{mg} \mathrm{g}^{-1}$ ) [54], $\mathrm{NaA}$ and $\mathrm{NaX}$ zeolites (Qe 118.9 and $106.4 \mathrm{mg} \mathrm{g}^{-1}$ ) [55], the adsorption capacity of BioSeNPs is higher than most of the common adsorbents used for zinc removal such as aluminosilicates, non-modified zeolite, bentonite or activated carbon (see Table 1).

Table 1. Maximum Qe-Zn of common adsorbents for $\mathrm{Zn}^{2+}$ ions at relevant conditions

\begin{tabular}{|c|c|c|c|c|}
\hline Adsorbent & Q max & $\mathrm{pH}$ & $\begin{array}{c}\text { Concentration } \\
\left(\mathrm{mg} \mathrm{L}^{-1}\right) \\
\mathrm{i}=\text { initial conc. } \\
\mathrm{e}=\text { equilibrium } \\
\text { conc. }\end{array}$ & Reference \\
\hline BioSeNPs & 60 & 6.5 & $200(\mathrm{i})$ & This study \\
\hline $\begin{array}{c}\text { Hydrous manganese } \\
\text { dioxide }\end{array}$ & $57.2,85.0$ & 6.0 & $\begin{array}{c}18.3(\mathrm{e}) \\
{[40,56]}\end{array}$ \\
\hline Graphene oxide & 345 & 5.0 & $100(\mathrm{e})$ & {$[57]$} \\
\hline
\end{tabular}


Manuscript submitted to Chemical Engineering Journal

\begin{tabular}{|c|c|c|c|c|}
\hline Aluminosilicates & 6.5 & 6.5 & $65.4(\mathrm{i})$ & {$[58]$} \\
\hline $\mathrm{Al}_{2} \mathrm{O}_{3}$ & 22.9 & 6.5 & $195.9(\mathrm{i})$ & {$[58]$} \\
\hline PVA/EDTA resin & 38.7 & 6.0 & $40(\mathrm{i})$ & {$[54]$} \\
\hline Dowex HCR S/S resin & 172.2 & 6.0 & $18(\mathrm{e})$ & {$[54]$} \\
\hline $\begin{array}{c}\text { Sodium rich bentonite } \\
\text { Al-pillared Na-rich } \\
\text { bentonite }\end{array}$ & 23.6 & 6.9 & $97.3(\mathrm{e})$ & {$[41]$} \\
\hline $\begin{array}{c}\text { Commercial activated } \\
\text { powder carbon }\end{array}$ & 20.5 & 7.0 & $400(\mathrm{e})$ & {$[4.3$} \\
\hline
\end{tabular}

This study opens perspectives to develop a novel adsorption technology where BioSeNPs present in the effluent of an UASB reactor treating selenium oxyanions containing wastewater $[9,26]$ is used as a metal adsorbent. It is important to note that the BioSeNPs are always present in the fore mentioned effluent due to microbial conversion of dissolved selenium oxyanions to BioSeNPs and these BioSeNPs has to be removed prior to discharging of the effluent [9]. Figure 4 demonstrated that the regulatory discharge concentration of zinc can be achieved by use of BioSeNPs at the tested conditions. It was also observed that at the appropriate metal to BioSeNPs ratio, $1: 1$ in this study, more than $97 \%$ of BioSeNPs can be retained in the settled sludge or removed from the effluent of an UASB reactor treating selenium oxyanion wastewater by a simple cost-effective gravity settling. The settled BioSeNPs loaded with zinc metal then can be used for recovery of the heavy metal and BioSeNPs.

\section{CONCLUSION}


Manuscript submitted to Chemical Engineering Journal

In this study, the adsorption of $\mathrm{Zn}^{2+}$ ions on BioSeNPs was investigated. Adsorption of $\mathrm{Zn}^{2+}$ ions on BioSeNPs follows a two-step process at near-neutral $\mathrm{pH}$ values and follows ligand-like (type II) mechanisms at acidic $\mathrm{pH}$. Furthermore, $\mathrm{Zn}^{2+}$ ions adsorbs to BioSeNPs mainly through inner-sphere complexation. Major advantages of using BioSeNPs as an adsorbent are the material's fast kinetics and capacity to adsorb more than $75 \%$ of the maximum adsorption capacity even at $\mathrm{pH}$ values below 3.9. The $\zeta$-potential of BioSeNPs changed from $-31 \mathrm{mV}$ to $-15 \mathrm{mV}$ after interaction with the $\mathrm{Zn}^{2+}$ ions, leading to aggregation of the BioSeNPs and subsequent settling of the colloidal suspension. This allows recovering the metal loaded BioSeNPs by simple gravity settling as observed in experiments with synthetic zinc wastewaters. This study provides understanding of $\mathrm{Zn}^{2+}$ ions adsorption onto BioSeNPs, which can be exploited to develop a new heavy metal removal process based on BioSeNPs produced out of effluents of UASB reactors treating selenium oxyanions rich wastewaters.

\section{ASSOCIATED CONTENT}

The SI contains methods related to analytical measurements procedures of ICPMS, SEM-EDXS, XRD, XPS, Malvern nanosizer and IC. It further contains extra figures and tables with experimental data as noted in the text.

\section{ACKNOWLEDGMENTS}

The authors are thankful to Dr. Pakshi Rajan Kanan (IIT Guwahati, India) and Domician Dominic (UNESCO-IHE, Delft) for helping with the experiments, Ferdi Battles, Lyzette Robbemont, Don van Galen (UNESCO-IHE, Delft) for the ICP-MS measurements, Marc Strampraad and Shaak Lispeth (TU-Delft, The Netherlands) for 


\section{ACCEPTED MANUSCRIPT}

Manuscript submitted to Chemical Engineering Journal

allowing access to high speed centrifuge, Gilles Catillon for XRD analysis (Université

Paris-Est, Marne-la-Vallée), and Elfi Christalle (Helmholtz-Zentrum Dresden-

Rossendorf) for SEM-EDXS measurements.

Author Contributions

The manuscript was written through contributions of all authors. All authors have given approval to the final version of the manuscript.

Funding Sources

This research was supported through the Erasmus Mundus Joint Doctorate Environmental Technologies for Contaminated Solids, Soils, and Sediments (ETeCoS $\left.{ }^{3}\right)$ (FPA n ²010-0009).

\section{REFERENCES}

[1] A. Singh, R.K. Sharma, M. Agrawal, F.M. Marshall, Health risk assessment of heavy metals via dietary intake of foodstuffs from the wastewater irrigated site of a dry tropical area of India, Food Chem. Toxicol. 48 (2010) 611-619.

[2] M. Hua, S. Zhang, B. Pan, W. Zhang, L. Lv, Q. Zhang, Heavy metal removal from water/wastewater by nanosized metal oxides: a review, J. Hazard. Mater. 211-212 (2012) 317-331.

[3] Z. Reddad, C. Gerente, Y. Andres, P. Le Cloirec, Adsorption of several metal ions onto a low-cost biosorbent: kinetic and equilibrium studies, Environ. Sci. Technol. 36 (2002) 2067-73.

[4] F. Arias, T.K. Sen, Removal of zinc metal ion $\left(\mathrm{Zn}^{2+}\right)$ from its aqueous solution by kaolin clay mineral: A kinetic and equilibrium study, Colloids Surfaces A Physicochem. Eng. Asp. 348 (2009) 100-108.

[5] J. Wang, S. Zheng, Y. Shao, J. Liu, Z. Xu, D. Zhu, Amino-functionalized $\mathrm{Fe}_{3} \mathrm{O}_{4} @ \mathrm{SiO}_{2}$ core-shell magnetic nanomaterial as a novel adsorbent for aqueous heavy metals removal, J. Colloid Interface Sci. 349 (2010) 293-299..

[6] R. Jain, G. Gonzalez-Gil, V. Singh, E. D. Van Hullebusch, F. Farges, P.N.L. Lens, Biogenic Selenium Nanoparticles: Production, Characterization and Challenges,in: A. Kuman, J.N. Govil, (Eds.), Nanobiotechnology, Studium Press LLC, USA, 2014, pp 361-390. 
[7] R.S. Oremland, M.J. Herbel, J.S. Blum, S. Langley, T.J. Beveridge, P.M. Ajayan, T. Sutto, A.V. Ellis, S. Curran, Structural and spectral features of selenium nanospheres produced by Se-respiring bacteria, Appl. Environ. Microbiol. 70 (2004) 52-60.

[8] S. Dhanjal, S.S. Cameotra, Aerobic biogenesis of selenium nanospheres by Bacillus cereus isolated from coalmine soil., Microb. Cell Fact. 9 (2010) 52-63.

[9] B. Buchs, M.W.-H. Evangelou, L. Winkel, M. Lenz, Colloidal properties of nanoparticular biogenic selenium govern environmental fate and bioremediation effectiveness., Environ. Sci. Technol. 47 (2013) 2401-2407.

[10] Y. Bai, F. Rong, H. Wang, Y. Zhou, X. Xie, J. Teng, Removal of copper from aqueous solution by adsorption on elemental selenium nanoparticles, J. Chem. Eng. Data 56 (2011) 2563-2568

[11] N.C. Johnson, S. Manchester, L. Sarin, Y. Gao, I. Kulaots, R.H. Hurt, Mercury vapor release from broken compact fluorescent lamps and in situ capture by new nanomaterial sorbents. Environ. Sci. Technol. 42 (2008) 5772-5778.

[12] J.W. Fellowes, R.A.D. Pattrick, D.I. Green, A. Dent, J.R. Lloyd, C.I. Pearce, Use of biogenic and abiotic elemental selenium nanospheres to sequester elemental mercury released from mercury contaminated museum specimens, J. Hazard. Mater. 189 (2011) 660-669.

[13] S. Jiang, C.T. Ho, J.-H. Lee, H. Van Duong, S. Han, H.-G. Hur, Mercury capture into biogenic amorphous selenium nanospheres produced by mercury resistant Shewanella putrefaciens 200, Chemosphere. 87 (2012) 621-624.

[14] O.V. Kharissova, H.V.R. Dias, B.I. Kharisov, B.O. Pérez, V.M.J. Pérez, The greener synthesis of nanoparticles, Trends Biotechnol. 31 (2013) 240-248.

[15] A.L. Stroyuk, A.E. Raevskaya, S. Ya, V.M. Dzhagan, D.R.T. Zahn, S. Schulze, Structural and optical characterization of colloidal Se nanoparticles prepared via the acidic decomposition of sodium selenosulfate, Colloids Surfaces A Physicochem. Eng. Asp. 320 (2008) 169-174.

[16] M. Quintana, E. Haro-poniatowski, J. Morales, N. Batina, Synthesis of selenium nanoparticles by pulsed laser ablation, Appl. Surf. Sci. 195 (2002) 175-186.

[17] T. Wang, L. Yang, B. Zhang, J. Liu, Extracellular biosynthesis and transformation of selenium nanoparticles and application in $\mathrm{H}_{2} \mathrm{O}_{2}$ biosensor, Colloids Surf. B. Biointerfaces. 80 (2010) 94-102.

[18] M. Lenz, A.C. Van Aelst, M. Smit, P.F.X. Corvini, P.N.L. Lens, Biological production of selenium nanoparticles from waste waters, Mater. Res. 73 (2009) 721724.

[19] K.M. Hambidge, N.F. Krebs, Zinc deficiency: a special challenge, J. Nutr. 137 (2007) 1101-1105.

[20] W. Naito, M. Kamo, K. Tsushima, Y. Iwasaki, Exposure and risk assessment of zinc in Japanese surface waters, Sci. Total Environ. 408 (2010) 4271-4284.

[21] United States Environmental Protection Agency website, http://water.epa.gov/drink/contaminants/secondarystandards.cfm. (access date: 14/09/2014)

[22] Food and Agriculture Organization of the United Nations, FAO Corporate Document Repository, http://www.fao.org/docrep/x5624e/x5624e04.htm (access date: 14/09/2014) 
Manuscript submitted to Chemical Engineering Journal

[23] Pollutants in urban wastewater and sewage sludge, ISBN 92-894-1735-8, Environment Directorate-General - European Commission: Luxembourg, (2001) http://ec.europa.eu/environment/waste/sludge/pdf/sludge_pollutants.pdf

[24] D.-B. Li, Y.-Y. Cheng, C. Wu, W.-W. Li, N. Li, Z.-C. Yang, Z.-H. Tong, H.-Q. Yu, Selenite reduction by Shewanella oneidensis MR-1 is mediated by fumarate reductase in periplasm, Sci. Rep. 4 (2014) 3735.

[25] J. Kessi, K.W. Hanselmann, Similarities between the abiotic reduction of selenite with glutathione and the dissimilatory reaction mediated by Rhodospirillum rubrum and Escherichia coli, J. Biol. Chem. 279 (2004) 50662-50669.

[26] M. Lenz, E.D. Van Hullebusch, G. Hommes, P.F.X. Corvini, P.N.L. Lens, Selenate removal in methanogenic and sulfate-reducing upflow anaerobic sludge bed reactors, Water Res. 42 (2008) 2184-21944.

[27] K. Roest, H.G.H.J. Heilig, H. Smidt, W.M. de Vos, A.J.M. Stams, A.D.L. Akkermans, Community analysis of a full-scale anaerobic bioreactor treating paper mill wastewater, Syst. Appl. Microbiol. 28 (2005) 175-185.

[28] J. Dobias, E.I. Suvorova, R. Bernier-latmani, Role of proteins in controlling selenium nanoparticle size, Nanotechnology 22 (2011) 195605.

[29] M. Zhao, J.R. Duncan, R.P. van Hille, Removal and recovery of zinc from solution and electroplating effluent using Azolla filiculoides, Water Res. 33 (1999) 15161522. .

[30] C. Nuengjamnong, J. Hyang, J. Cho, C. Polprasert, K. Ahn, Membrane fouling caused by extracellular polymeric substances during microfiltration processes, Desalination 179 (2005) 117-124

[31] N. Kayaalp, C. Kinaci, N. Dizge, N. Hamidi, Correlation of filtration resistance with microbial polymeric substances extracted from membranes in a submerged membrane bioreactor, Clean Soil Air Water 42 (2014) 1-9

[32] N. Tejo Prakash, N. Sharma, R. Prakash, K.K. Raina, J. Fellowes, C.I. Pearce, J.R. Llyod, R.A.D. Pattrick, Aerobic microbial manufacture of nanoscale selenium: exploiting nature's bio-nanomineralization potential, Biotechnol. Lett. 31 (2009) 18571862.

[33] K.-Y. Shin, J.-Y. Hong, J. Jang, Heavy metal ion adsorption behavior in nitrogendoped magnetic carbon nanoparticles: isotherms and kinetic study, J. Hazard. Mater. 190 (2011) 36-44.

[34] F.Q. Guo, K. Lu, Microstructural evolution of an as-quenched amorphous Se sample, Physical Review B 57 (1998) 10414.

[35] V. Bansal, D. Rautaray, A. Bharde, K. Ahire, A. Sanyal, A. Ahmad, A. M. Sastry, Fungus-mediated biosynthesis of silica and titania particles, Journal of Mater. Chemistry, 15 (2005) 2583-258.

[36] V. Bansal, P. Poddar, A. Ahmad, M. Sastry, Room-temperature biosynthesis of ferroelectric barium titanate nanoparticles, J. Am. Chem. Soc. 128 (2006) 11958-11963

[37] N. Graf, E. Yegen, T. Gross, A. Lippitz, W. Weigel, S. Krakert, A. Terfort, W.E.S. Unger, XPS and NEXAFS studies of aliphatic and aromatic amine species on functionalized surfaces, Surf. Sci. 603 (2009) 2849-2860.

[38] S. Senapati, A. Ahmad, M.I. Khan, M. Sastry, R. Kumar, Extracellular biosynthesis of bimetallic Au-Ag alloy nanoparticles., Small. 1 (2005) 517-5200. 
Manuscript submitted to Chemical Engineering Journal

[39] NIST X-ray Photoelectron Spectroscopy Database, Version 4.1 (National Institute of Standards and Technology, Gaithersburg, 2012), http://srdata.nist.gov/xps/. (access date: $14 / 09 / 2014$ )

[40] S.B. Kanungo, S.S. Tripathy, S.K. Mishra, B. Sahoo, Adsorption of $\mathrm{Co}^{2+}, \mathrm{Ni}^{2+}$, $\mathrm{Cu}^{2+}$, and $\mathrm{Zn}^{2+}$ onto amorphous hydrous manganese dioxide from simple (1-1) electrolyte solutions, J. Colloid Interface Sci. 269 (2004) 11-21.

[41] W. Matthes, F.W. Madsen, G. Kahr, Sorption of heavy metals cations by Al and Zr-hydroxyl-intercalated and pillared bentonite, Clays and clays material 47 (1999) 617629.

[42] D.D. Do, Adsorption analysis: equilibria and kinetics, Imperial College Press, London, 1998

[43] K.L. Nuttall, A model for metal selenide formation under biological conditions, Med. Hypotheses 24 (1987) 217-2211.

[44] W. Zhang, Z. Yang, J. Liu, Z. Hui, W. Yu, A hydrothermal synthesis of orthorhombic nanocrystalline cobalt diselenide $\mathrm{CoSe}_{2}$, Mater. Res. Bull. 35 (2000) 2403-2408.

[45] Y. Li, Y. Ding, H. Liao, Y. Qian, Room-temperature conversion route to nanocrystalline mercury chalcogenides $\mathrm{HgE}(\mathrm{E}=\mathrm{S}, \mathrm{Se}, \mathrm{Te})$, J. Phys. Chem. Solids 60 (1999) 965-968.

[46] H. Su, Y. Xie, B. Li, Y. Qian, A simple, convenient, mild hydrothermal route to nanocrystalline CuSe and $\mathrm{Ag}_{2} \mathrm{Se}$, Mater. Res. Bull. 35 (2000) 465-469

[47] R.R. Navarro, K. Tatsumi, K. Sumi, M. Matsumura, Role of anions on heavy metal sorption of a cellulose modified with poly(glycidyl methacrylate) and polyethyleneimine, Water Res. 35 (2001) 2724-2730.

[48] Z. Wang, S.-W. Lee, J.G. Catalano, J.S. Lezama-Pacheco, J.R. Bargar, B.M. Tebo, D.E. Giammar, Adsorption of uranium( $(\mathrm{VI})$ to manganese oxides: X-ray absorption spectroscopy and surface complexation modeling, Environ. Sci. Technol. 47 (2013) 850-858.

[49] G. McKay, J.F. Porter, Equilibrium parameters for the sorption of copper, cadmium and zinc ions onto peat, J. Chem. Technol. Biotechnol. 69 (1997) 309-320.

[50] A.G. Boricha, Z.V.P. Murthy, Preparation, characterization and performance of nanofiltration membranes for the treatment of electroplating industry effluent, Sep. Purif. Technol. 65 (2009) 282-289

[51] S.M. Kanawade, R.W. Gaikwad, Removal of zinc ions from industrial effluent by using cork powder as adsorbent, Int. J. Chem. Eng. Appl. 2 (2011) 199-201.

[52] S.I. Amer, Treating metal finishing wastewater, Environmental Technology; Aquachem Inc: Missouri City, TX, (1998)

http://aquachem-inc.com/Treating\%20Metal\%20Finishing\%20Wastewater.pdf (access date: $14 / 09 / 2014)$

[53] U. Kouakou, A.S. Ello, J.A. Yapo, A. Trokourey, Adsorption of iron and zinc on commercial activated carbon, J.Environ.Chemistry Ecotoxicol. 5 (2013) 168-17

[54] Y. Zhang, Y. Li, L. Yang, X. Ma, L. Wang, Z. Ye, Characterization and adsorption mechanism of $\mathrm{Zn}^{2+}$ removal by PVA/EDTA resin in polluted water, J. Hazard. Mater. 178 (2010) 1046-1054. 
Manuscript submitted to Chemical Engineering Journal

[55] D. Nibou, H. Mekatel, S. Amokrane, M. Barkat, M. Trari, Adsorption of $\mathrm{Zn}^{2+}$ ions onto $\mathrm{NaA}$ and $\mathrm{NaX}$ zeolites: kinetic, equilibrium and thermodynamic studies, J. Hazard. Mater. 173 (2010) 637-646.

[56] Q. Su, B. Pan, S. Wan, W. Zhang, L. Lv, Use of hydrous manganese dioxide as a potential sorbent for selective removal of lead, cadmium, and zinc ions from water, J. Colloid Interface Sci. 349 (2010) 607-612

[57] R. Sitko, E. Turek, B. Zawisza, E. Malicka, E. Talik, J. Heimann, A. Gagor, B. Feist, R. Wrzalik, Adsorption of divalent metal ions from aqueous solutions using graphene oxide, Dalton Trans. 42 (2013) 5682-5689.

[58] A. Miyazaki, I. Balint, Y. Nakano, Solid-liquid interfacial reaction of $\mathrm{Zn}^{2+}$ ions on the surface of amorphous aluminosilicates with various $\mathrm{Al} / \mathrm{Si}$ ratios, Geochim. Cosmochim. Acta 67 (2003) 3833-38444. 
Manuscript submitted to Chemical Engineering Journal
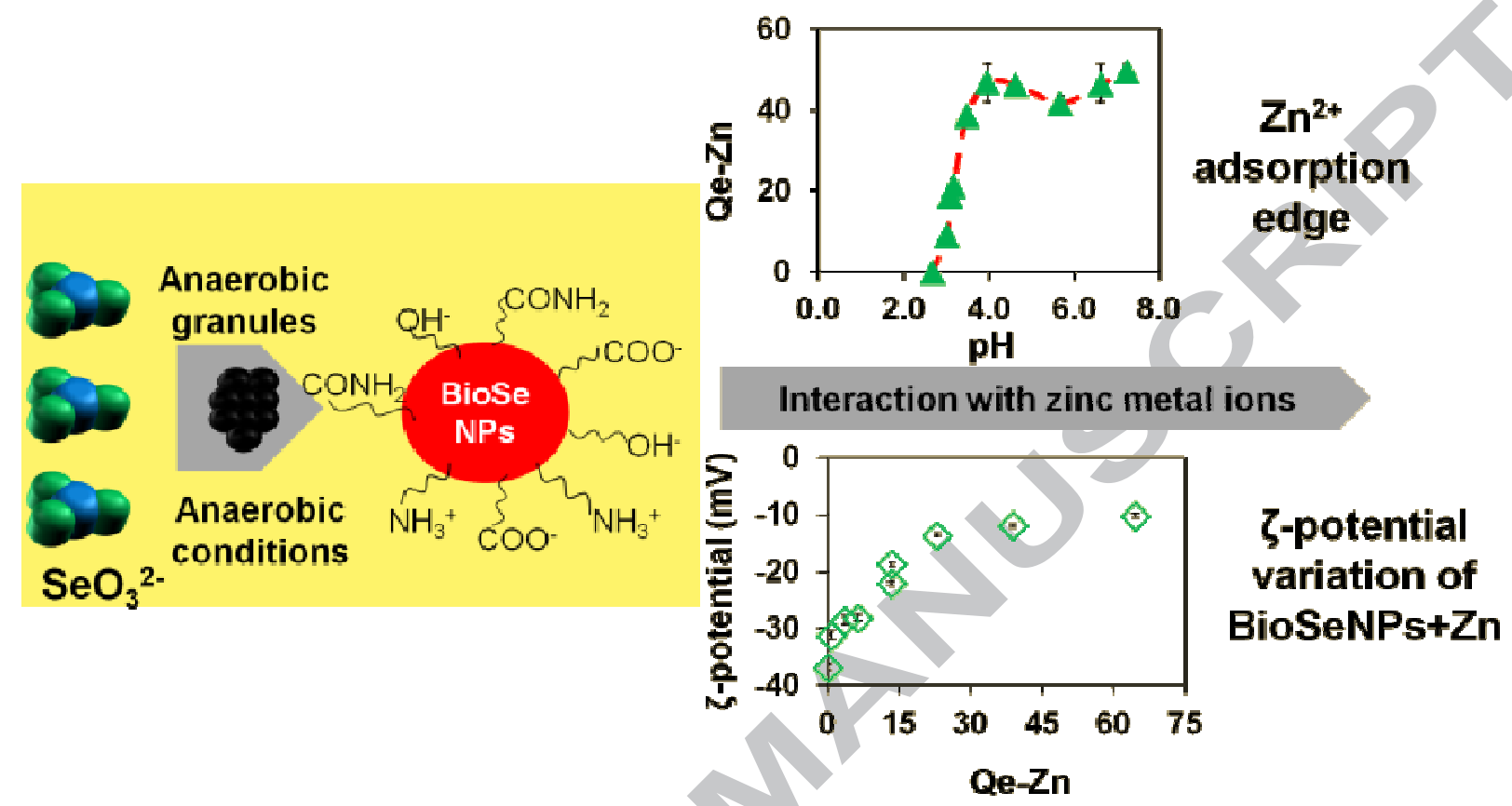
Manuscript submitted to Chemical Engineering Journal

\section{HIGHLIGHTS}

- $70 \%$ of $\mathrm{Zn}^{2+}$ adsorption on BioSeNPs was completed in first minute of the reaction.

- Adsorption of $\mathrm{Zn}^{2+}$ on BioSeNPs follows two-step mechanism at near-neutral $\mathrm{pH}$.

- Adsorption of $\mathrm{Zn}^{2+}$ on BioSeNPs follows ligand-like (type II) mechanism at low $\mathrm{pH}$.

- BioSeNPs loaded with $\mathrm{Zn}^{2+}$ have lower colloidal stability vis-a-vis BioSeNPs without $\mathrm{Zn}^{2+}$. 